\title{
Growth and Feed Conversion Response of Four Female Aseel Chicken Varieties to Antibiotic and Probiotic
}

\author{
Zia-ud-Din ${ }^{1}$, Muhammad Nauman Aftab ${ }^{2}$, Tanveer Hussain ${ }^{3, *}$, Irfana Iqbal $^{4}$ \\ and Asma Zafar 5 \\ ${ }^{1}$ CASVAB, University of Balochistan, Quetta \\ ${ }^{2}$ Institute of Industrial Biotechnology, Government College University, Lahore \\ ${ }^{3}$ Department of Molecular Biology, Virtual University of Pakistan, Lahore \\ ${ }^{4}$ Department of Zoology, Lahore College for Women University, Lahore \\ ${ }^{5}$ Department of Biotechnology, University of Central Punjab, Lahore
}

\begin{abstract}
A B S T R A C T
Indigenous Aseel female chicken (120 birds) comprising of four varieties (Lakha, Mushki, Peshawari and Mianwali) was fed for 42-days experimental period on antibiotic and probiotic supplemented ration. The results showed that the female growth, weight gain, FCR and economics varied significantly for feed supplements as well as for chicken varieties $(\mathrm{P}<0.05)$. The chickens given feed with probiotic $(@ 1 \mathrm{~g} /$ $\mathrm{kg}$ of feed were of more economic value than those fed on antibiotic supplemented feed and control with highest live body weight of $183.58 \pm 6.31 \mathrm{~g}$ gaining $143.13 \pm 6.37 \mathrm{~g}$ weight, multiplying their weight $4.56 \pm 0.17$ times over the initial body weight with feed intake of $668.82 \pm 31.11 \mathrm{~g}$ showing most efficient FCR (4.67 \pm 0.25$)$ with least mortality and highest net profit (Rs.1677, 0.35 cost benefit ratio). Among varieties, Mushki showed more economic value than rest of the varieties with highest live body weight of $169.78 \pm 8.23 \mathrm{~g}$, gaining $130.61 \pm 7.92 \mathrm{~g}$ weight, multiplying their weight $4.41 \pm 0.22$ times over the initial body weight with feed intake of $658.95 \pm 37.70 \mathrm{~g}$ showing slightly less efficient FCR $(5.09 \pm 0.47)$ with no mortality and highest net profit (Rs.1432, 0.44 CBR). Hence, the households and commercial farmers are suggested to prefer Mushki variety of Aseel chicken as attempt to produce Aseel females and probiotic supplementation would be of high economic viability for such flocks.
\end{abstract}

\begin{tabular}{l} 
Article Information \\
\hline Received 14 August 2018 \\
Revised 11 January 2019 \\
Accepted 20 February 2019 \\
Available online 01 October 2019 \\
Authors' Contribution \\
ZD designed the study. MNA \\
performed the study. Th corrected and \\
finalized the manuscript. II performed \\
the trial. AZ performed the statistical \\
studies. \\
Key words \\
Aseel chicken, Probiotic, Antibiotic, \\
Performance, FCR, Mortality, CBR.
\end{tabular}

\section{INTRODUCTION}

$\mathrm{T}$ he current investment in poultry industry in Pakistan is more than Rs. 200.0 billion. Poultry sector has shown a robust growth@8-10\% annually reflecting its inherent potential. During 2014-15, this sector contributed 1.3\% in GDP while its contribution in agriculture and livestock stood at 6.3 and $11.2 \%$, respectively. The poultry value added at current factor cost has increased from Rs. 130.7 billion (2013-14) to 140.5 billion (2014-15) showing an increase of $7.5 \%$ as compared to the previous year (GoP, 2015). According to the latest Economic Survey of Pakistan (GoP, 2015), the production of meat from poultry was 10.74 thousand tons from 932 thousand poultry birds. The details regarding commercial poultry indicated 794.63 million broiler production, 42.65 million layers, 10.70 million breeding stock, 829.99 million day-old chicks, 11.307 million eggs and 960.65 thousand tons meat. The rural poultry has also played a significant role in

\footnotetext{
* Corresponding author: tanveer.hussain@vu.edu.pk 0030-9923/2020/0015-0001 \$ 9.00/0

Copyright 2020 Zoological Society of Pakistan
}

bridging the gap between supply and requirement of animal protein for its ever increasing human population (Alders and Pym, 2009). However, poor productive potentials of rural Desi native chickens (Bhatti et al., 1990) and lack of genetically improved indigenous breeds (Sonaiya and Swan, 2007) has been one of the most important factors affecting the further pace of development in this sector. To increase growth rate, feed conversion efficiency, broodiness, egg size and egg production in Desi native chickens in Pakistan. Yaqoob et al. (1965), Ahmad et al. (1969) and Bhatti et al. (1990) have suggested modification in the feed formulation. Guèye (1998) and Tadelle et al. (2000) have also indicated poor productive potentials of native African chickens (). However, Desi native chickens have been reported to possess better resistance to diseases and centuries old adaptation to local rigorous environmental conditions (Ahmad et al., 1969; Bhatti et al., 1990). As egg production is a genetically controlled character (Fairfull, 1990) so the possibility of improvement in productive performance of native chickens through selective breeding has also been indicated by several investigations (Leong and Jalaludin, 1982; Ali and Hasnath, 1983; Guèye, 1998; Sahota et al., 2003). 
The aseel chicken is characterized by high body weight, but poor egg production potential thus leading to lower progeny size due to erratic ovulation, short clutches and broodiness. The production potential of aseel varieties has yet not been fully exploited for not using improved production techniques including the supplementation of feed with probiotic and antibiotic on this breed of chickens (Usman et al., 2013).

Probiotics are live microorganisms either bacteria or yeast which when locally applied or ingested in sufficient amount, confer one or more specified health benefits for the host (Anal and Singh, 2007). In animal feed, it is used as an alternative to antibiotics that are used as feed additives. The use of some antimicrobial drugs has been prohibited by the US Food and Drug Administration in food animals. The bacteria which are ingested could make colonies in the gastrointestinal tract of the bird; this is the right point to administer the probiotics microorganisms to the chickens (Fuller, 1989). The use of microorganisms as probiotics can make the period short for stabilizing the micro flora. This micro flora regulation can serve to improve weight gain, FCR as well as immune competence and intestinal health of the chickens (Panda et al., 2000). The microorganisms of Bacillus probiotics are exogenous that's why have a high ability to stimulate local intestinal immunity (Sanders et al., 2003). Bacillus subtilus in shrimp reduces the stress, improves the quality of water and shrimp health as well (Decamp and Moriarty, 2006). According to Decamp and Moriarty (2006) Bacillus licheniformis used for shrimp production was observed to control pathogenic bacteria as well as their virulence, stimulated the immune system as it improved gut flora thus substituting antibiotics. Bacillus subtilis (strain MA 139) was isolated by Guo et al. (2006) which showed improved daily gain increased body weight as well as decreased pathogenic E. coli in weaned piglets (Wolfenden et al., 2010). Drinking water and feed are the routes commonly used for administrating probiotic preparation (Watkins and Kratzer, 1984). This study was mainly aimed at studying the performance of aseel native female chicken as affected by supplementation of probiotic and antibiotic for achieving enhanced results for weight gain, FCR and reduced mortality. Moreover, four varieties of native aseel chicken were used to compare their relative response to probiotic and antibiotic.

\section{MATERIALS AND METHODS}

This experiment was performed to study the performance of four varieties of aseel native female chicken (Lakha, Mushki, Peshawari and Mianwali) as affected by supplementation of probiotic and antibiotic for achieving enhanced results for weight gain, feed conversion ratio (FCR) and reducing mortality. This study was carried out in the months of January and February where the average maximum temperature was $22^{\circ} \mathrm{C}$ and average minimum temperature was $11.4^{\circ} \mathrm{C}$. Thus total of 720 days old aseel chicks were kept in the same environment without any treatment for seven days to adopt the environment. After adaptation period, 120 female birds were isolated and divided randomly into 3 treatment groups each of 40 with 10 birds of each variety in each group; control group (no feed additive), antibiotic group (4 $\mathrm{g}$ neomycin $/ \mathrm{kg}$ of feed) and probiotic group (1 $\mathrm{g}$ probiotic $1.5 \times 10^{10} \mathrm{CFU}$ B. licheniformis KT443923/kg of feed). Suitable cages were allotted to the experimental birds and the environment was well-ventilated, open sided and the poultry house was under similar management conditions up to six weeks. Initially, they were weighed and tagged individually for identification then placed in an open sided well ventilated poultry house under similar management conditions for six weeks. Clean and fresh drinking water was in free access to the birds through drinking nipples and were provided with both artificial and natural daylight. A balanced ration based on NRC (1984) standards and on recommendations of Leeson and Summers (2005) for broiler starter and grower diets was fed by experimental birds. The performance of the birds like body weight $(\mathrm{g})$, weight gain $(\mathrm{g})$, feed intake $(\mathrm{g})$, feed conversion ratio (FCR) and mortality was observed. The dead birds' weight was used to adjust for feed consumption. This experiment was conducted according to randomized complete block design (RCBD) and collected data was analyzed by using analysis of variance (ANOVA) techniques (Steel et al., 1997) using SAS, 9.1, (SAS, 2004) portable software. The means were compared by using Duncan's Multiple Range test (Duncan, 1955).

\section{RESULTS AND DISCUSSION}

\section{Body weight and weight gain}

Table I shows the effect of feed supplemented with antibiotics and probiotics for 42 days on the body weight of female of four varieties of aseel chicken. After 42 days experimentation, the birds fed on probiotic (@1 $1 \mathrm{~g} / \mathrm{kg}$ feed) supplemented ration multiplied their weight 4.56 \pm 0.17 times over the initial body weight, while antibiotic group of chickens ( $4 \mathrm{~g}$ neomycin $/ \mathrm{kg}$ of feed) multiplied $3.99 \pm 0.17$ times their initial weight; whereas control group chickens multiplied $3.43 \pm 0.20$ times their initial weight. The varietal response of aseel chicken indicated that Mushki females multiplied their weight $4.41 \pm 0.22$ times during 42 days experimental period over their initial body weight; followed by Lakha, Peshawari and Mianwali aseel varieties with $4.13 \pm 0.24,3.97 \pm 0.26$ and $3.49 \pm 0.21$ folds increase, respectively. The interactive effect of chicken variety $\times$ feed supplement exhibited that probiotic (@) $1 \mathrm{~g} / \mathrm{kg}$ 
feed) $\times$ Lakha, Peshawar and Mushki females multiplied $4.82 \pm 82,4.81 \pm 0.41$ and $4.76 \pm 4.76$ times their weight during 42 days over their initial weight, respectively. Regardless of feed supplementation, Mianwali variety of aseel chicken multiplied their weight in a short time over their initial weight. On the basis of feed, we preferred probiotic-supplemented feed because this group of birds gained 4.56 times more weight, whereas control groups gained 3.99 and 3.43 times more weight compared to their initial weight. Based on varieties, Mushki birds obtained higher weight (4.41 times) as compared to their initial weights. Therefore, first preference was given to Mushki followed by Lakha, Peshawari. The Mushki females were ranked third and fourth, respectively. The results of the present research are in accordance with those of Decamp and Moriarty (2006) who conducted the study on shrimps, and reported that probiotic application on host as feed supplement can not only reduce the stress on the animals but also improve the quality of water where shrimps were kept. Similar to this, a comparative trend was observed in birds health as compare to their initial weight in this study. More body weight of probiotic group birds was also observed as compared to other groups. According to Decamp and Moriarty (2006), the probiotics used for chicken production were observed to control pathogenic bacteria as well as their virulence, stimulated the immune system as it improved gut flora thus it substituted antibiotics.

The average body weight of female chickens was markedly increased when fed probiotic supplemented feed $(183.58 \pm 6.31)$ compared to those fed on antibiotic and control. The varietal response of aseel chicken indicates that Mushki females were significantly $(\mathrm{P}<0.05)$ heavier followed by Peshawari, Lakha and Mianwali. The interactive response of chicken variety $\times$ feed supplement showed highest body weight in Mushki, Lakha, Peshawari and Mianwali when feed supplemented with probiotic. The least body weight was recorded for Mianwali, although the body weight ranked second for the all the aseel chicken varieties under antibiotic feed supplementation, besides least final body weight was recorded for all chicken varieties when fed on control feed. For maximization of body weight in females of aseel chicken, the feed may be supplemented with probiotic @ $1 \mathrm{~g} / \mathrm{kg}$ of feed. Ahmad et al. (2014) have also reported higher body weight in aseel variety Mushki when they were fed on ration supplemented with feed additives. Similarly, Malik et al. (2008) reported highest body weight in older birds $(2382 \pm 15)$ followed by medium and younger, but the feed additive effect on the birds of all ages was significant. Panda et al. (2000) reported that probiotics supplementation in feed caused high ability to stimulate local intestinal immunity among the indigenous chicken breeds.
Table I.- Body weight (g), weight gain (g) and folds of weight gain of 4 female aseel chicken varieties as influenced by diets containing antibiotic and probiotic at $6^{\text {th }}$ week of age.

\begin{tabular}{|c|c|c|c|}
\hline Variables & Body weight (g) & Weight gain (g) & $\begin{array}{c}\text { Folds of } \\
\text { weight gain }\end{array}$ \\
\hline \multicolumn{4}{|l|}{ Diets } \\
\hline Control & $129.29 \pm 6.04^{\mathrm{d}}$ & $90.46 \pm 6.50^{\mathrm{c}}$ & $3.43 \pm 0.22^{\mathrm{c}}$ \\
\hline Antibiotic & $155.00 \pm 7.27^{\mathrm{c}}$ & $115.96 \pm 6.83^{b}$ & $3.99 \pm 0.17^{\mathrm{b}}$ \\
\hline Probiotic & $183.58 \pm 6.31^{\mathrm{b}}$ & $143.13 \pm 6.37^{\mathrm{a}}$ & $4.56 \pm 0.17^{\mathrm{a}}$ \\
\hline \multicolumn{4}{|l|}{ Varieties } \\
\hline Lakha & $157.06 \pm 9.06^{\mathrm{d}}$ & $118.611 \pm 8.88^{b}$ & $4.13 \pm 0.24^{\mathrm{bcd}}$ \\
\hline Mushki & $169.78 \pm 8.23^{\mathrm{cd}}$ & $130.61 \pm 7.92^{\mathrm{b}}$ & $4.41 \pm 0.22^{\mathrm{abc}}$ \\
\hline Peshawari & $160.72 \pm 10.75^{\mathrm{cd}}$ & $120.22 \pm 10.51^{b}$ & $3.97 \pm 0.26^{\mathrm{cd}}$ \\
\hline Mianwali & $136.28 \pm 6.94^{e}$ & $96.61 \pm 7.33^{\mathrm{c}}$ & $3.49 \pm 0.21^{\mathrm{d}}$ \\
\hline \multicolumn{4}{|c|}{ Diets $x$ Varieties } \\
\hline \multicolumn{4}{|l|}{ Control } \\
\hline Lakha & $129.83 \pm 10.99^{\mathrm{hij}}$ & $93.00 \pm 11.62^{\mathrm{jk}}$ & $3.62 \pm 0.43^{\mathrm{def}}$ \\
\hline Mushki & $149.67 \pm 14.43^{\text {efghij }}$ & $111.33 \pm 15.98^{\mathrm{fghijk}}$ & $4.07 \pm 0.61^{\text {cdef }}$ \\
\hline Peshawari & $123.00 \pm 12.67^{\mathrm{ij}}$ & $83.17 \pm 12.94^{\mathrm{k}}$ & $3.11 \pm 0.37^{\mathrm{ef}}$ \\
\hline Mianwali & $142.67 \pm 11.09^{j}$ & $74.33 \pm 8.31^{\mathrm{k}}$ & $2.94 \pm 0.32^{\mathrm{f}}$ \\
\hline \multicolumn{4}{|l|}{ Antibiotic } \\
\hline Lakha & $148.67 \pm 16.63^{\text {efghij }}$ & $110.33 \pm 16.58^{\text {ghijk }}$ & $3.96 \pm 0.49^{\text {cdef }}$ \\
\hline Mushki & $158.33 \pm 11.44^{\text {defghi }}$ & $121.67 \pm 9.65^{\text {defghij }}$ & $4.35 \pm 0.24^{\text {beed }}$ \\
\hline Peshawari & $170.33 \pm 18.81^{\text {cdefghi }}$ & $128.17 \pm 16.96^{\text {defghi }}$ & $3.99 \pm 0.31^{\text {cdef }}$ \\
\hline Mianwali & $142.67 \pm 11.09^{\text {fghij }}$ & $103.67 \pm 11.36^{\mathrm{hjk}}$ & $3.67 \pm 0.32^{\mathrm{def}}$ \\
\hline \multicolumn{4}{|l|}{ Probiotic } \\
\hline Lakha & $192.67 \pm 4.86^{\mathrm{abcd}}$ & $152.50 \pm 4.45^{\text {abcde }}$ & $4.82 \pm 0.15^{\mathrm{abcd}}$ \\
\hline Mushki & $201.34 \pm 6.69^{\mathrm{abc}}$ & $158.83 \pm 6.80^{\mathrm{abcd}}$ & $4.76 \pm 0.22^{\mathrm{abcd}}$ \\
\hline Peshawari & $188.83 \pm 14.24^{\mathrm{abcde}}$ & $149.33 \pm 14.65^{\text {abcdef }}$ & ${ }^{f} 4.81 \pm 0.41^{\text {abcd }}$ \\
\hline Mianwali & $151.50 \pm 13.09^{\text {defghij }}$ & $111.83 \pm 13.96^{\mathrm{abcd}}$ & $3.87 \pm 0.41^{\mathrm{def}}$ \\
\hline
\end{tabular}

The weight gain of female aseel chicken was studied for their varietal response under different feed supplements and significant influence of probiotic and antibiotics feed supplementation on weight gain was observed $(\mathrm{P}<0.05)$. After 42 days of experimentation, the average weight gain of females was higher when feed was supplemented with probiotic @ $1 \mathrm{~g} / \mathrm{kg}$ feed, followed by chickens given antibiotic (4 g Neomycin/kg of feed) feed supplementation; while minimum weight gain was determined in control (commercial feed). The varietal response aseel showed that Mushki females gained maximum weight; followed by Peshawari and Lakha; while the minimum weight gain during 42 days period was recorded for Mianwali. The variety $\times$ feed supplement interaction suggested that the 
maximum weight gain was produced by probiotic feed supplementation $\times$ variety Mushki, Lakha, Peshawari and Mianwali and the individual weight gain for all chicken varieties ranked second under antibiotic feed supplementation; while control group of chicken gained lowest weight. However, the varietal interaction of aseel females with antibiotic feed supplementation showed that of Peshawari responded better for weight gain than Mushki to antibiotic feed supplementation. On the basis of overall weight gain performance of female aseel chicken, probiotic feed supplementation @ $1 \mathrm{~g} / \mathrm{kg}$ of feed is suggestible. Similar results have also been reported by a number of past researchers from different parts of the world. Ahmad et al. (2014) achieved significantly higher body weight (2188 $\pm 26 \mathrm{~g} / 16$ weeks) in post-moult phase in Mushki variety of Assel chicken. Earlier, Mazzuco et al. (2005) had also reported higher body weight in the same breed; and such increase in body weight was due to progression in age of chickens as well as feeding with high protein ration. Sanders et al. (2003) reported that probiotic supplementation improved immunity in the chicken and hence resulted in an increased body weight and weight gain during certain rearing period.

Table II shows effect of feed supplemented with antibiotics and probiotics fed for 42 days on the feed intake and FCR of female of four varieties of aseel chicken. The probiotic (@1 $1 \mathrm{~g} / \mathrm{kg}$ feed) supplemented feed was maximally consumed by chicken compared to the antibiotic (4 $\mathrm{g}$ neomycin $/ \mathrm{kg}$ of feed) supplemented feed and control birds. The varietal behavior of aseel females towards feed consumption showed that Mushki females consumed highest amount of feed followed by Lakha, Peshawar and Mianwali. The chicken variety $\times$ feed supplement interaction indicates that the maximum feed consumption was done by Mushki, Lakha and Peshawar aseel chicken varieties and they consumed higher amounts of feed supplemented with probiotic ( $1 \mathrm{~g} / \mathrm{kg}$ feed), while the lowest feed consumption was done by the interaction of Mianwali $\times$ control feed. This indicates that Mushki, Lakha and Peshawari were more responsive towards the treated feed as compared to Mianwali variety. On the basis of overall feed consumption, probiotic feed supplementation (a) $1 \mathrm{~g} / \mathrm{kg}$ of feed not only improves the palatability of feed but also results in positive impacts on the overall growth of the birds. The results so achieved are further confirmed earlier by Mead and Impey (1986) who showed that best performance in chicken was achieved when a mixture of probiotics was used. Ahmad et al. (2014) reported significantly higher feed intake $(8.505 \pm 0.065 \mathrm{~kg} / 16$ weeks) in aseel chickens variety Mushki. Zia et al. (2016) observed that feed intake differed significantly in different varieties and strains of aseel chicken.
Table II.- Feed intake and feed efficiency (FCR) of four female aseel chicken varieties as influenced by diets containing antibiotic and probiotic at $6^{\text {th }}$ week of age.

\begin{tabular}{|c|c|c|}
\hline Variables & Feed intake (g) & FCR \\
\hline \multicolumn{3}{|l|}{ Diets } \\
\hline Control & $571.44 \pm 38.12^{\mathrm{b}}$ & $5.46 \pm 0.32^{\mathrm{b}}$ \\
\hline Antibiotic & $571.44 \pm 35.45^{b}$ & $4.92 \pm 0.21^{\mathrm{c}}$ \\
\hline Probiotic & $668.82 \pm 31.11^{\mathrm{a}}$ & $4.67 \pm 0.25^{\mathrm{d}}$ \\
\hline \multicolumn{3}{|l|}{ Varieties } \\
\hline Lakha & $606.51 \pm 44.31^{\mathrm{c}}$ & $5.15 \pm 0.42^{\mathrm{a}}$ \\
\hline Mushki & $658.95 \pm 37.70^{\mathrm{bc}}$ & $5.09 \pm 0.47^{\mathrm{ab}}$ \\
\hline Peshawari & $585.03 \pm 48.31^{\mathrm{c}}$ & $4.93 \pm 0.35^{\mathrm{bc}}$ \\
\hline Mianwali & $465.42 \pm 30.05^{\mathrm{d}}$ & $4.91 \pm 0.43^{\mathrm{c}}$ \\
\hline \multicolumn{3}{|c|}{ Diets $x$ Varieties } \\
\hline \multicolumn{3}{|l|}{ Control } \\
\hline Lakha & $529.53 \pm 76.39^{\mathrm{defg}}$ & $5.64 \pm 0.27^{\mathrm{bc}}$ \\
\hline Mushki & $625.19 \pm 92.57^{\text {abcdef }}$ & $5.59 \pm 0.34^{\mathrm{bc}}$ \\
\hline Peshawari & $432.79 \pm 68.73 \mathrm{f}^{\mathrm{g}}$ & $5.19 \pm 0.24^{\mathrm{ef}}$ \\
\hline Mianwali & $399.19 \pm 37.10^{\mathrm{g}}$ & $5.42 \pm 0.29^{\text {bcd }}$ \\
\hline \multicolumn{3}{|l|}{ Antibiotic } \\
\hline Lakha & $557.85 \pm 92.20^{\text {defg }}$ & $5.01 \pm 0.19^{\mathrm{ef}}$ \\
\hline Mushki & $605.08 \pm 48.46^{\text {bcdefg }}$ & $4.97 \pm 0.08^{\mathrm{efg}}$ \\
\hline Peshawari & $628.96 \pm 84.55^{\text {abcdef }}$ & $4.93 \pm 0.32^{\text {efg }}$ \\
\hline Mianwali & $493.85 \pm 54.75^{\mathrm{efg}}$ & $4.76 \pm 0.11^{\mathrm{fgh}}$ \\
\hline \multicolumn{3}{|l|}{ Probiotic } \\
\hline Lakha & $732.14 \pm 29.60^{\text {abcd }}$ & $4.79 \pm 0.16^{\mathrm{fgh}}$ \\
\hline Mushki & $746.58 \pm 35.19^{\mathrm{abcd}}$ & $4.71 \pm 0.33^{\mathrm{fgh}}$ \\
\hline Peshawari & $693.35 \pm 67.63^{\text {abcde }}$ & $4.66 \pm 0.29^{\mathrm{gh}}$ \\
\hline Mianwali & $503.21 \pm 59.28^{\mathrm{efg}}$ & $4.53 \pm 0.15^{\mathrm{hi}}$ \\
\hline
\end{tabular}

\section{Feed consumption and feed conversion efficiency}

The FCR reflects the amount of feed consumed by the birds for gaining one kilogram weight and the FCR of female aseel chicken was calculated on the basis of weight gain. The effect of feed supplemented with probiotic/antibiotic and varietal influence on FCR was significant $(\mathrm{P}<0.05)$ (Table II). The feed supplemented with probiotic @ $1 \mathrm{~g} / \mathrm{kg}$ feed improved the feed efficiency of chicken maximally (4.67 \pm 0.25 ), followed by chickens given antibiotic ( $4 \mathrm{~g}$ neomycin $/ \mathrm{kg}$ of feed) feed supplementation (4.92 \pm 0.21$)$; while lowest feed efficiency $(5.46 \pm 0.32)$ was analyzed for control birds (commercial feed). Good FGR was observed in the study of Khan et al. (2019) when a feed additive was supplemented with broiler feed. The varietal response aseel female chicken showed that Mianwali variety showed best FCR followed by Peshawari and Mushki; while relatively weaker FCR was calculated for variety Lakha. The chicken variety $\times$ feed supplement interaction showed 
that most efficient FCR interaction was Mianwali variety $\times$ probiotic $(1 \mathrm{~g} / \mathrm{kg}$ feed $)$, followed by Peshawari variety $\times$ probiotic, Mushki variety $\times$ probiotic and Mianwali variety $\times$ antibiotic and Lakha variety $\times$ probiotic; while lowest feed efficiency was noted in Lakha variety $x$ control interaction. These findings are in accordance with those of Wolfenden et al. (2010) who reported that due to probiotic feed supplementation, the bird's immunity was improved significantly and hence increased body weight without increasing feed resulted in the improvement of the feed conversion efficiency. Ahmad et al. (2014) reported that feed efficiency varied significantly among the aseel chicken varieties. Yasmeen et al. (2008) reported improvement in feed conversion efficiency of aseel chicken with the decreasing age. Contrarily, Vargas et al. (2009) reported that feed conversion efficiency is mainly associated with the bird age.

\section{Mortality}

In case of mortality of female aseel chicken that were given feed with antibiotic and probiotics, total mortality was $1.53 \%$ during six weeks experimental period; $0.83 \%$ in control group, $0.55 \%$ in antibiotic group and $0.13 \%$ in probiotic treated group. It was experienced that the aseel birds given feed supplemented with probiotic suffered almost zero mortality and only $0.13 \%$ appeared during second week; $0.55 \%$ in antibiotic group; while highest percentage 0.83 was recorded in control group. This clearly indicates that feed supplementation with probiotic and antibiotic was effective to control mortality rate also. However, feed with probiotic was highly beneficial for aseel chicken saving almost $100 \%$ flocks. Similar results have also been reported by Malik et al. (2008) who testified that mortality in indigenous chicken decreased with feed supplementation with probiotic. Panda recorded least mortality in Indigenous chicken when probiotics supplementation in feed was ensured (Panda et al., 2000). Moreover, the used probiotics, i.e. Saccharomyces cerevisiae and Bacillus coagulans have immunomodulatory properties in broilers as has already been reported by Bai et al. (2013) and Panda et al. (2005). Increased phagocytosis by macrophages and improved oxidative burst activity of avian heterophils has been reported after administration of Bacillus-based probiotics (Higgins et al., 2008; Farnell, 2006) in broilers diet.

\section{Economic analysis}

The economics of feed supplements (antibiotic and probiotic) as well as varieties of aseel chicken was analyzed and it was observed (Table III) that the chicken fed on ration with probiotic earned highest net profit (Rs.
1677) with 0.35 cost benefit ratio CBR, followed by those fed on antibiotics earning Rs. 1188/- net profit with 0.28 CBR; while control earned least net profit of Rs. 816/- with 0.21 CBR. It clearly suggested that aseel chicken females responded positively and more profitably to probiotic as compared to antibiotic as feed supplement. Moreover, the reduction in mortality increased the net return of income, in spite of no effect on body weight gain in probiotic treated groups. The efficacy of probiotic depends upon dose, types of microbes present in the probiotics, kinds of the gut microbial population, types of basal diet ingredients used in the diet formulation, prevalent stress condition, etc. (Musa et al., 2009; Marco et al., 2013).

Table III.- Analysis for economic viability of feeding groups.

\begin{tabular}{lccc}
\hline & \multicolumn{3}{c}{ Groups } \\
\cline { 2 - 4 } & Control & Antibiotic & Probiotic \\
\hline Total birds & 40 & 40 & 40 \\
Birds survived & 34 & 36 & 39 \\
Total cost & 3876 & 4284 & 4758 \\
Total income & 4692 & 5472 & 6435 \\
(open market sale) & & & \\
Net profit & 816 & 1188 & 1677 \\
CBR & 0.21 & 0.28 & 0.35 \\
\hline
\end{tabular}

Table IV.- Analysis for economic viability of female aseel chicken varieties.

\begin{tabular}{lcccc}
\hline & \multicolumn{4}{c}{ Varieties of aseel breed } \\
\cline { 2 - 5 } & Lakha & Mianwali & Mushki & Peshawari \\
\hline Total birds & 30 & 30 & 30 & 30 \\
Birds survived & 28 & 25 & 29 & 27 \\
Total cost & 3284 & 3125 & 3237 & 3272 \\
Total income & 4200 & 3775 & 4669 & 3955 \\
(open market sale) & & & & \\
Net profit & 916 & 650 & 1432 & 683 \\
CBR & 0.28 & 0.21 & 0.44 & 0.21 \\
\hline
\end{tabular}

The economics of rearing females of native aseel chicken varieties (Table IV) showed that the Mushki chicken variety earned highest net profit (Rs. 1432) with 0.44 CBR, followed by Lakha earning Rs. 916/- net profit with 0.28 CBR; Peshawari earning Rs. 683/- net profit with $0.21 \mathrm{CBR}$; while the females of Mianwali aseel chicken earned least net profit of Rs. 650/- with 0.21 CBR. The results conclude that Mushki aseel female were of more market value as compared to Lakha, Peshawar and Mianwali varieties. Hence, the household and commercial farmers are suggested to prefer Mushki variety of aseel 
chicken while attempt to produce aseel females.

\section{CONCLUSIONS}

The growth, mortality, FCR and economics of aseel female chicken varied significantly due to feed supplementation with probiotics, antibiotics and response of aseel chicken varieties to feed supplementation also varied significantly $(\mathrm{P}<0.05)$. The feed supplemented with probiotic (@1g/kg of feed) proved to be highly beneficial for female aseel chicken causing increased live body weight, gaining higher weight, multiplying their weight more times over the initial body weight, increasing feed intake, showing most efficient FCR with least mortality and highest net profit/CBR. Among aseel varieties, Mushki females showed more market value than the rest of the varieties with the highest weight gain, FCR and CBR. The farmers are suggested to prefer Mushki variety of aseel hens for commercial production and probiotic feed supplementation might give them higher net profits and reduced mortality risk.

\section{ACKNOWLEDGEMENTS}

The authors thankfully acknowledge cooperation extended by late Prof. Dr. M. Akram, University of Veterinary and Animal Sciences Lahore Pakistan.

\section{Statement of conflict of interest}

The authors declare no conflict of interest.

\section{REFERENCES}

Ahmad, K., Ahmad, M. and Chaudhry, M., 1969. A critical study on various aspects of lyallpur silver black breed as compared to imported and local breeds of chickens. West Pak. J. agric. Res, 7: 132138.

Ahmad, Z., Sahota, A., Akram, M., Khalique, A., Jatoi, A., Shafique, M., Usman, M. and Khan, U., 2014. Pre and post-moult productive efficiency in four varieties of indigenous aseel chicken during different production cycles. J. Anim. Pl. Sci., 24: 1276-1282.

Alders, R. and Pym, R., 2009. Village poultry: Still important to millions, eight thousand years after domestication. World's Poult. Sci. J., 65: 181-190. https://doi.org/10.1017/S0043933909000117

Ali, A. and Hasnath, M., 1983. A study on the heritability estimates of body weight of indigenous chickens. Bangladesh Vet. J., 17: 19-24.

Anal, A.K. and Singh, H., 2007. Recent advances in microencapsulation of probiotics for industrial applications and targeted delivery. Trends Fd. Sci. Technol., 18: 240-251.

Bhatti, B., Qureshi, M., Sahota, A. and Ashraf, M., 1990. Evolving of a chicken with potential of higher meat and egg yield for rural areas of pakistan. In: Proceedings $3^{\text {rd }}$ International Congress, Pakistan Vet. Med. Assoc., pp. 340-345.

Bai, S.P., Wu, A.M., Ding, X.M., Lei, Y., Bai, J., Zhang, K.Y. and Chio, J.S., 2013. Effects of probiotic supplemented diets on growth performance and intestinal immune characteristics of broiler chickens. Poult. Sci., 92: 663-670. https://doi. org/10.3382/ps.2012-02813

Decamp, O. and Moriarty, D., 2006. Probiotics as alternative to antimicrobials: Limitations and potential. World Aquacul., 37: 60-62.

Duncan, D.B., 1955. Multiple range and multiple f tests. Biometrics, 11: 1-42.

Fairfull, R., 1990. Genetics of egg production in chickens. In: Poultry breeding and genetics (ed. R.D. Crawford). Elsevier Science Publishers, Amsterdam, pp. 705-759.

Farnell, M.B., 2006. Upregulation of oxidative burst and degranulation in chicken heterophils stimulated with probiotic bacteria. Poult. Sci., 85: 1900-1906. https://doi.org/10.1093/ps/85.11.1900

Fuller, R., 1989. Probiotics in man and animals. J. appl. Bact., 66: 365-378. https://doi. org/10.1111/j.1365-2672.1989.tb05105.x

GOP (Government of Pakistan), 2015. Economic survey of Pakistan. Ministry of Finance, Government of Pakistan.

Guèye, E.H.F., 1998. Village egg and fowl meat production in Africa. World's Poult. Sci. J., 54: 7386. https://doi.org/10.1079/WPS19980007

Guo, X., Li, D., Lu, W., Piao, X. and Chen, X., 2006. Screening of Bacillus strains as potential probiotics and subsequent confirmation of the in vivo effectiveness of Bacillus subtilis ma139 in pigs. Antonie Van Leeuwenhoek, 90: 139-146. https:// doi.org/10.1007/s10482-006-9067-9

Higgins, S.E., Higgins, J.P., Wolfenden, A.D., Henderson, S.N., Torres-Rodriguez, A., Tellez, G. and Hargis, B., 2008. Evaluation of a Lactobacillusbased probiotic culture for the reduction of Salmonella enteritidis in neonatal broiler chicks. Poult. Sci., 87: 27-31. https://doi.org/10.3382/ ps.2007-00210

Khan, K., Zaneb, Z., Rehman, Z., Maris, H. and Rehman, H., 2019. Effect of phytase supplementation on growth performance in broiler chickens. Pakistan 
J. Zool., 51: 731-735. http://dx.doi.org/10.17582/ journal.pjz/2019.51.2.531.535

Leeson, S. and Summers, J., 2005. Commercial poultry nutrition. Department of Animal and Poultry Science, University of Guelph, Ontario, Canada.

Leong, E. and Jalaludin, S., 1982. The poultry industries of south east asia-the need for an integrated farming system for small poultry producers. World's Poult. Sci. J., 38: 213-219. https://doi.org/10.1079/ WPS19820017

Malik, H.M., Ehsan-Ul-Haq and Ahmad, F., 2008. Effect of age and body weight at molting on the performance of broiler breeder hens under environmental control houses in Pakistan. Pakistan Vet. J., 28: 189-193.

Musa, H.H., Wu, S.L., Zhu, C.H., Seri, H.I. and Zhu, G.Q., 2009. The potential benefits of probiotics in animal production and health. J. Anim. Vet. Adv. 8: $313-321$.

Marco, M.L. and Tachon, S., 2013. Environmental factors influencing the efficacy of probiotic bacteria. Curr. Opin. Biotech., 24: 207-213. https://doi.org/10.1016/j.copbio.2012.10.002

Mazzuco, H., McMurtry, J., Kuo, A. and Hester, P., 2005. The effect of pre-and postmolt diets high in n-3 fatty acids and molt programs on skeletal integrity and insulin-like growth factor-I of white leghorns. Poult. Sci., 84: 1735-1749. https://doi. org $/ 10.1093 / \mathrm{ps} / 84.11 .1735$

Mead, G. and Impey, C., 1986. Current progress in reducing salmonella colonization of poultry by competitive exclusion. Soc. appl. Bact. Sympos. Ser., 15: 67S-75S.

NRC, 1984. Nutrient requirements of poultry, $8^{\text {th }}$ rev. ed. The National Academies Press, Washington, DC. https://doi.org/10.17226/19397

Panda, A., Reddy, M., Rao, S.R., Raju, M. and Praharaj, N., 2000. Growth, carcass characteristics, immunocompetence and response to Escherichia coli of broilers fed diets with various levels of probiotic. Arch. Geflügelk., 64: 152-156.

Panda, A.K., Raju, M.V.L.N., Rama-Rao, S.V. and Sharma, S.R., 2005. The influence of supplementation of lactobacillus sporogenes on the performance of broilers. Indian J. Anim. Nutr., 22: 37-40.

Sahota, A., Bhatti, B. and Akhtar, L., 2003. Comparative productive performance of desi parent chickens and their first progeny maintained on deep litter system. Pakistan Vet. J., 23: 7-10.

Sanders, M., Morelli, L. and Tompkins, T., 2003.
Sporeformers as human probiotics: Bacillus, sporolactobacillus and brevibacillus. Compreh. Rev. Fd. Sci. Fd. Safe., 2: 101-110. https://doi. org/10.1111/j.1541-4337.2003.tb00017.x

Sonaiya, E.B. and Swan, S., 2007. Small scale poultry production-Technical guide. Daya Publishing House, New Delhi, India.

Steel, R., Torrie, J. and Dickey, D., 1997. Principles and procedures of statistics: A biometrical approach. McGraw-Hill, New York.

SAS, 2004. SAS/STAT user guide, version 9.1. 2. SAS Institute Inc., Cary, NC.

Tadelle, D., Alemu, Y. and Peters, K., 2000. Indigenous chickens in Ethiopia: Genetic potential and attempts at improvement. World's Poult. Sci. J., 56: 45-54. https://doi.org/10.1079/WPS20000005

Usman, M., Ahmad, Z., Akram, M., Hussain, J., Mehmood, S., Shafiq, M., Rehman, A., Ahmad, S. and Iqbal, A., 2013. Pre and post moult productive performance of three age groups in four varieties of aseel chicken. Proc. Pakistan Congr. Zool., 13: 33.

Vargas, F., Baratto, T., Magalhães, F., Maiorka, A. and Santin, E., 2009. Influences of breeder age and fasting after hatching on the performance of broilers. J. appl. Poult. Res., 18: 8-14. https://doi. org/10.3382/japr.2008-00029

Watkins, B. and Kratzer, F., 1984. Drinking water treatment with a commercial preparation of a concentrated Lactobacillus culture for broiler chickens. Poult. Sci., 63: 1671-1673. https://doi. org/10.3382/ps.0631671

Wolfenden, R., Pumford, N., Morgan, M., Shivaramaiah, S., Wolfenden, A., Tellez, G. and Hargis, B., 2010. Evaluation of a screening and selection method for Bacillus isolates for use as effective directfed microbials in commercial poultry. Int. J. Poult. Sci., 9: 317-323. https://doi.org/10.3923/ ijps.2010.317.323

Yaqoob, M., Haider, S. and Siddiqui, M., 1965. Preliminary studies on the growth pattern and productive behaviour of local chicken. Pakistan J. agric. Sci., 2: 103-107.

Yasmeen, F., Mahmood, S., Hassan, M., Akhtar, N. and Yaseen, M., 2008. Comparative productive performance and egg characteristics of pullets and spent layers. Pakistan Vet. J., 28: 5-8.

Zia, W.M., Khalique, A., Naveed, S. and Hussain, J., 2016. Studies on growth pattern of different body measurements in indigenous aseel chicken fed with selenium supplemented diets. Indian J. Anim. Res., 51: 679-386. 